\title{
Nature, Incidence, and Symptomatology of Viruses Infecting Vanilla tahitensis in French Polynesia
}

\author{
M. Grisoni, Centre de Coopération Internationale en Recherche Agronomique pour le Développement, CIRAD/SDR, \\ BP 467, 98713 Papeete, French Polynesia; F. Davidson and C. Hyrondelle, Service du Développement Rural, BP \\ 13, 98735 Raiatea, French Polynesia; K. Farreyrol, School of Biological Sciences, The University of Auckland, PB \\ 92019, Auckland, New Zealand; M. L. Caruana, Centre de Coopération Internationale en Recherche Agronomique \\ pour le Développement, AMIS/PC TA 40/02, 34398 Montpellier cedex 5, France; and M. Pearson, School of Bio- \\ logical Sciences, The University of Auckland, New Zealand
}

\begin{abstract}
Grisoni, M., Davidson, F., Hyrondelle, C., Farreyrol, K., Caruana, M. L., and Pearson, M. 2004. Nature, incidence, and symptomatology of viruses infecting Vanilla tahitensis in French Polynesia. Plant Dis. 88:119-124.

A survey was carried out to identify the viruses infecting vanilla in French Polynesia and to assess their incidence. Virus identification was based on enzyme-linked immunosorbent assay (ELISA) and, for potyviruses, on the sequence of part of the coat protein and inoculation assays. Between 1998 and 1999, 3,610 vanilla plants from 49 plots in the Society Islands were indexed. Cymbidium mosaic virus (CymMV) was detected in 500 vines from 10 plots in the Leeward Islands. The data suggest that this virus has spread widely since its first detection in French Polynesia in 1986, most likely through the dissemination of symptomless infected cuttings. Viruses belonging to the Potyvirus genus were found in 674 plants from 27 plots in the four islands surveyed. Three distinct potyviruses have been identified: (i) Vanilla mosaic virus, (ii) Watermelon mosaic virus, and (iii) and a virus related to Bean common mosaic virus. The symptoms induced on Vanilla tahitensis by the three potyviruses can be differentiated from each other and from those due to CymMV. A significant proportion of the plants surveyed (97/476) were symptomatic but tested negative by ELISA for CymMV and the Potyvirus group. Odontoglossum ringspot virus was not detected in any sample tested.
\end{abstract}

Additional keyword: Potyvirus

Vanilla is the most-used flavor in the food industry. Natural vanilla is produced mainly from the fruit of two species of orchids: Vanilla planifolia G. Jackson, syn. Vanilla fragrans (Salisb.) Ames, (Bourbon type of vanilla) and $V$. tahitensis J. W. Moore (Tahitian type of vanilla). Close to 5,000 tonnes of vanilla beans are grown yearly worldwide and imports to consuming countries are worth about US\$200 million. More than $95 \%$ of commercial vanilla is of the Bourbon type. However, the aromatic properties peculiar to Tahitian vanilla make

Corresponding author: M. Grisoni

E-mail: michel.grisoni@cirad.fr

This work was funded by the government of French Polynesia.

Sequences of four isolates studied are registered in the EMBL database under the numbers AJ429522, AJ429523, AJ429524, and AJ429525.

* The $\boldsymbol{e}$-Xtra logo stands for "electronic extra" and indicates that the figures appear in color online.

Accepted for publication 1 July 2003.

Publication no. D-2003-1208-03R

(C) 2004 The American Phytopathological Society it a well-sought-after product and its cultivation is noticeably increasing in the Pacific region. French Polynesia was the first cultivation zone of $V$. tahitensis and remains the principal producer of Tahitian vanilla.

Six viruses have been reported to infect vanilla. Cymbidium mosaic virus (CymMV) and Odontoglossum ring spot virus (ORSV), two viruses commonly found in ornamental orchids, were first detected in vanilla by Wisler et al. (32) in the Society Islands (French Polynesia). CymMV later was reported on V. planifolia in other Pacific countries (22) and in Indian Ocean countries $(9,20)$. In Reunion Island and in Madagascar, it was linked with the presence of chlorotic and necrotic flecks on the leaves. A Potyvirus sp. causing a mosaic and severe malformations of leaves was described in French Polynesia on V. tahitensis and V. pompona (32). This virus is related serologically to Dasheen mosaic virus (DsMV) but is differentiated by its host range and tentatively is named Vanilla mosaic virus (VanMV). Pearson et al. (21) reported another Potyvirus sp. infecting $V$. planifolia in the kingdom of Tonga that differs from VanMV by its serological properties, host range, and symptomatology on the vine. It was first called
Vanilla necrosis virus (VNV) before Wang et al. (30) demonstrated it was a strain of Watermelon mosaic virus (WMV). Liefting et al. (17) reported from Tonga another Potyvirus sp. different from VanMV and WMV, but this remains to be confirmed. Pearson et al. (22) summarized the occurrence of these viruses on vanilla in several South Pacific countries. In addition, they reported the presence of Rhabdovirus-like particles in some samples from Fiji and Vanuatu, detected by electron microscopy of negatively stained sap extracts. More recently, Farreyrol et al. (8) reported the infection of vanilla plants by Cucumber mosaic virus (CMV) in both the Society Islands and Reunion Island.

Some of these viruses appear to produce diverse symptoms on the vanilla vines $(1,8,21)$, but the symptomatology and impact of these viruses in the field have received little attention. For French Polynesia, which hopes to develop intensive $V$. tahitensis plantations, these viruses represent a potentially serious threat. This study has been carried out to clarify and identify which of the viruses are infecting vanilla plants and the extent of their spread in the Society Islands. In particular, information regarding the efficiency of the detection methods, the symptoms of the viruses on the vine, and the mode of spread in the field will allow the development of control measures to limit the economic impact of viruses on the crop.

\section{MATERIALS AND METHODS}

Survey sites and sampling procedures. Several vanilla plots in the islands of Raiatea, Tahaa, Huahine, and Moorea were surveyed. Plots were distributed across different administrative subdivisions (districts), but favored those where the extension agents suspected the presence of disease. For each plot, between 30 and 150 evenly distributed clumps of vanilla vines on support trees or stakes were indexed in the following way. Vine vigor was graded on a 0 -to- 3 scale, where $0=$ dead or absent, $1=$ stunted or declining, $2=$ showing normal growth, and 3 = well-developed, showing vigorous growth. The presence of viral symptoms (flecking, mosaic and deformations, or abnormalities) was recorded 
and four to eight leaves were sampled to test for CymMV and viruses belonging to the Potyvirus group by enzyme-linked immunosorbent assay (ELISA). Segments of the vines showing pronounced or unusual symptoms were collected and propagated in an insect-proof shade house for further characterization.

Detection of CymMV, potyviruses, and ORSV. Leaf samples were tested by ELISA for the presence of (i) CymMV using specific antibodies from Agdia, Inc. (Elkhart, IN) and (ii) a virus of the genus Potyvirus with the Potyvirus group monoclonal antibody from Agdia, Inc.. For each sample, $0.6 \mathrm{~g}$ of tissue was ground in $6 \mathrm{ml}$ of carbonate buffer (4), $\mathrm{pH} 9.6$, containing $2 \%(\mathrm{wt} / \mathrm{vol})$ polyvinylpyrrolidone $(\mathrm{MW}=$ 40,000). For the detection of CymMV, the plant extracts were diluted fivefold in phosphate-buffered saline ( $\mathrm{pH}$ 7.4) containing $2 \%(\mathrm{wt} / \mathrm{vol})$ polyvinylpyrrolidone, and tested by indirect double-antibody sandwich ELISA with commercial antibodies and conjugate diluted at 1/300. For the detection of the potyviruses by platetrapped antigen (PTA)-ELISA, the plant extracts were tested at a final dilution of $1 / 30(\mathrm{wt} / \mathrm{vol})$.

The vines collected in the field and propagated in the shade house were checked additionally for infection by ORSV. This virus was detected by PTAELISA using polyclonal antibodies marketed by DSMZ (Braunschweig, Germany) and used at a 1/1,000 dilution. Several vines reacting with the Potyvirus group monoclonal antibody were additionally tested in PTA ELISA with six polyclonal antibodies directed against five known Potyvirus spp. (Table 1).

All reactions were performed in a volume of $100 \mu \mathrm{l}$ per well and each sample was tested in duplicate wells. Each plate included four negative controls from four separate virus-free vanilla leaves and a range of 1:3 serial dilutions of a positive control. Positive controls prepared from freeze-dried vanilla leaves that previously tested infected by CymMV and Potyvirus spp. ORSV-positive controls were prepared from leaves of an infected vanda orchid. Absorbance at $405 \mathrm{~nm}\left(A_{405}\right)$ was measured with a Digiscan spectrophotometer driven by the Digiwin software (version 3.1; ASYS Hitech, Eugendorf, Austria). The reaction was stopped when the positive control reached two $A_{405}$ units.

Samples were considered negative if the mean $A_{405}$ was lower than two times the mean of the negative control, and positive if higher than four times the mean of the negative control and above 0.1 unit. This threshold was based on statistical analysis (Student $t$ test) of data from 20 plates where the probability of a false positive using this threshold was always less than 0.01 . Values between two and four times the mean of the negative control were regarded as doubtful.

Partial sequencing of the Potyvirus coat protein gene. Reverse-transcription polymerase chain reaction (RT-PCR) was used to amplify a 300-bp fragment of the coat protein $(\mathrm{CP})$ gene of potyviruses from infected vines as described by MarieJeanne et al. (18). Briefly, total RNA was extracted from $0.1 \mathrm{~g}$ of vanilla leaf using

Table 1. Antibodies used for the identification of the potyviruses found in vanilla

\begin{tabular}{llll}
\hline Antiseruma & \multicolumn{1}{c}{ Homologous antigen strain, host } & \multicolumn{1}{c}{ Source } & $\begin{array}{c}\text { Working } \\
\text { dilution }\end{array}$ \\
\hline Potyvirus group & Not applicable & Agdia Corp. (USA) & $1 / 200$ \\
VanMV & VanMV Tahiti, Vanilla tahitensis & M. Pearson & $1 / 1,000$ \\
DsMV & Not provided by manufacturer & Agdia Corp. (USA) & $1 / 200$ \\
WMV & VNV Tonga, Nicotiana benthamiana & M. Pearson & $1 / 1,000$ \\
WMV & WMV, Cucumis melo & Biorad (France) & $1 / 500$ \\
CABMV & CABMV-0417 Morocco, Vigna unguiculata & DSMZ (Germany) & $1 / 1,000$ \\
BCMV & PStV-0337 Taiwan, Glicine max & DSMZ (Germany) & $1 / 500$ \\
\hline
\end{tabular}

a VanMV = Vanilla mosaic virus, DsMV = Dasheen mosaic virus, WMV = Watermelon mosaic virus, $\mathrm{VNV}=$ Vanilla necrosis virus, CABMV = Cowpea aphid-borne mosaic virus, $\mathrm{BCMV}=$ Bean common mosaic virus, $\mathrm{PStV}=$ Peanut stripe virus. the RNeasy plant minikit (Qiagen, Valencia, CA). This RNA $(2 \mu \mathrm{l})$ was incubated with $25 \mu \mathrm{l}$ of the reaction mix provided with the Access quick RT-PCR kit (Promega Corp., Madison, WI) and 25 $\mu \mathrm{mol}$ of each of the two degenerate primers designed to amplify part of the CP gene of potyviruses infecting the family Poaceae (18): Oligo1, 3'-ATG GT(A/C/T) TGG TG(C/T) AT(A/C/T) GA(A/G) $\mathrm{AA}(\mathrm{C} / \mathrm{T}) \mathrm{GG}-5^{\prime}$ and Oligo2, $3^{\prime}$-TGC TGC (G/T)GC (C/T)T TCA T(C/T) TG-5'.

Amplified DNA fragments were cloned into the pGEM-T-easy vector (Promega Corp.) and both strands sequenced by Genome Express (Grenoble, France). The sequences were compared with each other and with those deposited in the EMBL sequences databases using BLASTN. The percent homology between aligned sequences was calculated using the Clustal $\mathrm{W}$ and Identity Matrix modules of the Bioedit software (10).

Mechanical inoculations. Four serologically distinct Potyvirus isolates from infected vines were mechanically inoculated to several herbaceous species to determine their host range, and to virus-free vanilla vines to observe the symptoms they produced. For mechanical inoculation, $1 \mathrm{~g}$ of young leaf tissue was homogenized on ice in $5 \mathrm{ml} 0.05 \mathrm{M}$ phosphate buffer $(\mathrm{pH}$ 7.5), $0.3 \mathrm{~g}$ of carborundum (400 mesh), and $0.3 \mathrm{~g}$ of activated charcoal, using a mortar and pestle. Two young leaves (or cotyledons in the case of members of $\mathrm{Cu}$ curbitacae) of each test plant were rubbed with this extract on both the upper and lower sides and then rinsed with tap water. For each virus, three to six test plants of the same species were inoculated and the experiment was repeated once. After inoculation, the plants were grown and held in an insect-proof shade house (25 to $32^{\circ} \mathrm{C}$ ). Tests plants were observed regularly for symptoms and checked for virus systemic infection by ELISA 2 and 3 weeks after inoculation for herbaceous hosts and 6 and 10 weeks after inoculation for vanilla test plants.

\section{RESULTS}

Incidence of CymMV and potyviruses. Forty-nine plots were indexed by

Table 2. Incidence of symptoms and detection of Cymbidium mosaic virus (CymMV) and potyviruses in 49 vanilla plots in the Society islands

\begin{tabular}{|c|c|c|c|c|c|c|c|c|c|c|c|c|c|c|}
\hline \multirow[b]{2}{*}{ Island } & \multirow[b]{2}{*}{$\mathbf{N P I}^{\mathrm{e}}$} & \multicolumn{4}{|c|}{$\mathbf{N S}^{\mathbf{a}}$} & \multicolumn{5}{|c|}{$\mathbf{N P E}^{\mathrm{b}}$} & \multicolumn{2}{|c|}{ NSPE $^{c}$} & \multicolumn{2}{|c|}{ NSNE $^{\mathrm{d}}$} \\
\hline & & Fleck & Mosaic & Atyp & None & CymMV & Potyvirus & Both $^{\mathrm{f}}$ & Doubtful & Healthy & CymMV & Potyvirus & Fleck & Mosaic \\
\hline Tahaa & 994 & 1 & 77 & 108 & 808 & 2 & 224 & 7 & 15 & 746 & 2 & 80 & 0 & 4 \\
\hline Raiatea & 1,417 & 77 & 180 & 219 & 941 & 406 & 139 & 63 & 66 & 743 & 277 & 11 & 13 & 42 \\
\hline Huahine & 989 & 5 & 136 & 77 & 771 & 4 & 218 & 18 & 29 & 720 & 6 & 87 & 0 & 38 \\
\hline Moorea & 210 & 0 & 0 & 0 & 210 & 0 & 5 & 0 & 1 & 204 & 0 & 5 & 0 & 0 \\
\hline Total & 3,610 & 83 & 393 & 404 & 2730 & 412 & 586 & 88 & 111 & 2,413 & 285 & 183 & 13 & 84 \\
\hline
\end{tabular}

a NS: Number of symptomatic plants; Fleck = flecking, Mosaic = mosaic and deformation, Atyp = atypical symptoms, none = no symptoms.

${ }^{b}$ NPE: Number of plants positive in enzyme-linked immunosorbent assay (ELISA).

${ }^{c}$ NSPE: Number of symptomless plants positive in ELISA.

${ }^{\mathrm{d}}$ NSNE: Number of symptomatic plants negative in ELISA; Fleck = flecking, Mosaic $=$ mosaic and deformation.

e NPI: Number of plants indexed.

${ }^{\mathrm{f}}$ Plants co-infected by CymMV and a Potyvirus sp. 
ELISA between October 1998 and June 1999 on the islands of Tahaa, Raiatea, Huahine, and Moorea $(n=18,15,14$, and 2 plots, respectively). Plants infected by CymMV, at least one Potyvirus sp., or both were present in 30 of the 49 plots indexed by ELISA. In total, 1,086 of the 3,610 vines tested were virus infected (412 CymMV, 586 Potyvirus sp., 88 CymMV + Potyvirus sp.; Table 2). CymMV was detected in 10 plots on the islands of Raiatea, Tahaa, and Huahine (in 6, 3, and 1 plots, respectively), while potyviruses were detected in 27 plots on the four islands (in $10,9,7$, and 1 plots in Tahaa, Raiatea, Huahine, and Moorea, respectively). Vines co-infected by both virus types were found in six plots and represent $8.1 \%$ of the infected plants (88/1,086; Table 2). Virus incidence varied greatly from one vanilla plot to another: between 0.9 and $99 \%$ for CymMV and between 0.6 and $97 \%$ for potyviruses. There was no apparent correlation between the level of infection and either the type of support used or the age of the plots (data not shown). No clear or consistent correlation was found between the incidence of viruses in the field plots and the average vigor of the vines.

Symptoms were observed on the leaves of 880 plants; 83 plants showed flecking (Fig. 1), 393 showed mosaic and deformation, and 404 showed atypical symptoms (Table 2). Excluding atypical symptoms and doubtful ELISA results $\left(A_{405}\right.$ value between two and four times the negative

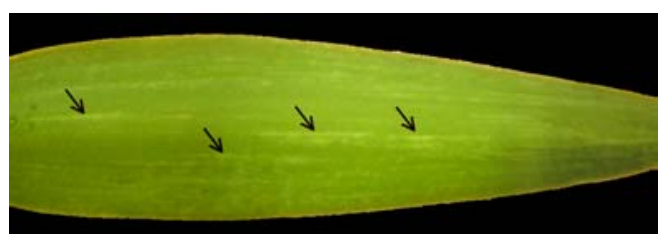

Fig. 1. Chlorotic flecks (arrows) following infection of Vanilla tahitensis by Cymbidium mosaic virus. control), visual diagnosis based on presence or absence of symptoms was in agreement with ELISA tests for $86 \%$ of the plants. However, many plants positive in ELISA did not exhibit symptoms. For CymMV, $57 \%$ of the plants $(285 / 500)$ positive in ELISA were symptomless. Conversely, $20.3 \%$ (97/476) of the symptomatic plants tested negative in ELISA for both virus types.

Serological characterization of the potyviruses. Of the 120 symptomatic vines collected from the field and maintained in an insect-proof shade house, 50 were tested with six antisera against five known Potyvirus spp. Each of the six virus-specific antibodies reacted with at least one sample and, reciprocally, all samples reacted with at least one of the antisera used (Table 3). These results indicate that the potyviruses infecting vanilla vines in French Polynesia are serologically related to five distinct potyviruses: VanMV in sample WP013; DsMV in samples WP013, WP021, WP043, WP073, and WP080; WMV (including VNV) in samples WP014, WP019, WP043, WP050, WP055, WP058, WP073, WP080, and WP099; Cowpea aphid-borne mosaic virus (CABMV) in samples WP080, WP086, WP088, and WP099; and Bean common mosaic virus (BCMV) in samples WP080, WP088, and WP099. Several vines reacted with a limited number of antibodies, showing distinct serological profiles, such as WP014 and WP019 (WMV only), WP021

Table 3. Reactions of a range of vanilla plants infected by different viruses when tested in enzyme-linked immunosorbent assay (ELISA) with various antisera

\begin{tabular}{|c|c|c|c|c|c|c|c|c|}
\hline \multirow[b]{2}{*}{ Virus isolate } & \multicolumn{8}{|c|}{ Antisera $^{a}$} \\
\hline & Origin $^{b}$ & Poty & VanMV & DsMV & VNV & WMV & CABMV & BCMV \\
\hline WP 013 & $\mathrm{R}$ & ++ & + & ++ & - & - & $\mathrm{d}$ & nd \\
\hline WP 014 & $\mathrm{R}$ & ++ & - & - & ++ & ++ & $\mathrm{d}$ & nd \\
\hline WP 019 & $\mathrm{~T}$ & ++ & - & - & + & $\mathrm{d}$ & - & - \\
\hline WP 021 & $\mathrm{R}$ & ++ & $\mathrm{d}$ & + & - & - & - & nd \\
\hline WP 043 & $\mathrm{H}$ & + & $\mathrm{d}$ & ++ & + & + & - & nd \\
\hline WP 050 & $\mathrm{H}$ & ++ & - & - & + & $\mathrm{d}$ & - & - \\
\hline WP 055 & $\mathrm{H}$ & ++ & - & $\mathrm{d}$ & ++ & + & $\mathrm{d}$ & $\mathrm{d}$ \\
\hline WP 058 & $\mathrm{H}$ & ++ & - & d & + & $\mathrm{d}$ & - & - \\
\hline WP 073 & $\mathrm{~T}$ & ++ & - & + & ++ & + & $\mathrm{d}$ & $\mathrm{d}$ \\
\hline WP 080 & $\mathrm{~T}$ & ++ & $\mathrm{d}$ & + & + & $\mathrm{d}$ & + & + \\
\hline WP 086 & $\mathrm{~T}$ & ++ & - & - & $\mathrm{d}$ & $\mathrm{d}$ & + & nd \\
\hline WP 088 & $\mathrm{~T}$ & ++ & - & - & - & $\mathrm{d}$ & + & + \\
\hline WP 099 & $\mathrm{~T}$ & ++ & - & - & - & + & + & + \\
\hline
\end{tabular}

a $++=$ Highly positive in ELISA (i.e., absorbance at $405 \mathrm{~nm}\left[A_{405}\right]$ greater than 10 times the healthy control), $+=$ positive in ELISA (i.e., $A_{405}$ greater than 4 times the healthy control), $-=$ negative in ELISA (i.e., $A_{405}$ less than 2 times the healthy control), d = doubtful in ELISA (i.e., $A_{405}$ between 2 and 4 times the healthy control), nd= not determined. Antisera are directed against Potyvirus group (Poty), Vanilla mosaic virus (VanMV), Dasheen mosaic virus (DsMV), Vanilla necrosis virus (VNV), Watermelon mosaic virus (WMV), Cowpea aphid borne mosaic virus (CABMV), and Bean common mosaic virus (BCMV).

b Origin of vanilla samples: $\mathrm{H}=$ Huahine, $\mathrm{R}=$ Raiatea, and $\mathrm{T}=$ Tahaa. 
DsMV and infected $V$. tahitensis, we failed in several attempts to infect this species with field isolates of DsMV.

WP019, which is serologically related to WMV (Tongan strain), was mechanically transmitted to watermelon (cv. Sugar Baby), melon (cv. Cantaloup), V. tahitensis and $V$. pompona, and $N$. benthamiana. Inoculated vanilla plants produced a mosaic. The leaf surface was embossed but with limited deformation of the leaf edge (Fig. 2B). On watermelon and melon, the infection induced small, systemic chlorotic spots on the leaves. The re-inoculation of vanilla plants from the infected melons reproduced the original symptomatology. The infected $N$. benthamiana plants showed mottling and deformation of the leaves.

WP010 and WP017 (reacting to BCMV and CABMV antisera), were inoculated into vanilla and several leguminous plants. Both were infectious to $V$. tahitensis and produced a diffuse mosaic (Fig. 2C). Phaseolus vulgaris (cv. Black Turtle 2) was infected and developed deformation and embossing of the leaves. However, we were unable to infect Vigna unguiculata, V. marina, or Macroptilum lathyroides with WP010 and WP017.

The virus-infected vanilla material collected in the field and maintained in a shade-house repeatedly tested ORSV free by ELISA (data not shown).

\section{DISCUSSION}

Our investigation, conducted between October 1998 and June 1999, confirmed the infection of the Tahitian vanilla vines by CymMV and VanMV as previously reported (32) but also demonstrated the occurrence of two other viruses.

The infection of Vanilla tahitensis by CymMV is often symptomless but, in certain cases, is accompanied by chlorotic flecks on the leaves. However, the symptoms in V. tahitensis appeared less severe than those reported in V. planifolia (1). In a previous survey conducted in 1986, CymMV was detected serologically in only 10 vines at two locations, 9 in Tahiti and 1 in Raiatea (32). Thirteen years later, this virus was detected in 500 vines in 10 plots on the Leeward Islands, mostly on the island of Raiatea but also in Tahaa and Huahine. Although a different detection procedure has been used in this study, it is likely that CymMV incidence has substantially increased through the movement of infected cuttings. Historical examination of plots typically indicates that the origin of infection in the plots is the use of infected cuttings. For example, cuttings from a plot in Tahiti where CymMV was diagnosed in 1986 were planted in a shade house of Huahine, which is the only plot infected by the CymMV on this island, and also in a plot of Raiatea that was subsequently found to be $100 \%$ infected by CymMV. In turn, two additional plots in Raiatea containing CymMV-infected plants were at least partly planted with vines from that $100 \%$ infected plot of Raiatea. Similarly, the distribution of the infected and healthy vines in a shade-house planted with vines of different origin clearly is related to the sources of the cuttings (data not shown). In contrast, the reservoir of virus constituted by ornamental orchids seems to play a negligible role in the infection of vanilla plots.

Two factors appear to favor the spread of the CymMV: (i) the symptoms are often absent or faint and (ii) CymMV, like most potexviruses, is easily transmitted mechanically from plant to plant (15). It can be assumed that the growers have, unknowingly, widely disseminated symptomless but infected cuttings from one plot to another. From these, the virus rapidly spreads to the whole plot by mechanical transmission, facilitated by injuries caused during the cultural practices (notably looping of the vines and manual pollination). A similar scenario for the spread of CymMV was described in shade-house cultivated vanilla in Reunion Island (16).

It also is probable that wide distribution of CymMV in the Society archipelago has occurred because of the absence of sanitary control of the vanilla cuttings. Numerous techniques are available for the detection of CymMV $(6,7,12,13,23,26,28,29,33)$ and the ELISA test used in this survey turned out to be robust, sensitive, and cost effective. It is now routinely used to check the planting material distributed to the vanilla growers.

Three different potyviruses were identified in the vanilla vines cultivated in French Polynesia, based on serological relationships and nucleotide sequences of a 327-nucleotide CP gene fragment. The first (WP013; Tables 3 and 4; Fig. 2A) is related to VanMV and to DsMV. It shared with the VanMV strains previously described $(31,32)$ its serological properties, symptomatology on $V$. tahitensis, and inability to infect taro and $N$. benthamiana. WP013 also is related serologically to DsMV and has $98 \%$ homology to the 109 central amino acids of the CP of DsMV accession U00122. However, at the nucleotide level, the identity between WP013 and U00122 is only $87 \%$ and, furthermore, the natural host range of DsMV is restricted largely to Araceae spp. (3). A DsMV isolate that naturally infects the orchid Spiranthes cernua has been reported recently but this isolate could not be mechanically transmitted to the two common DsMV araceous hosts Dieffenbachia and Philodendron (14). Similarly, several attempts to infect Areaceae spp. with WP013 (this study) and VanMV isolates have failed, as has transmission of field isolates of DsMV

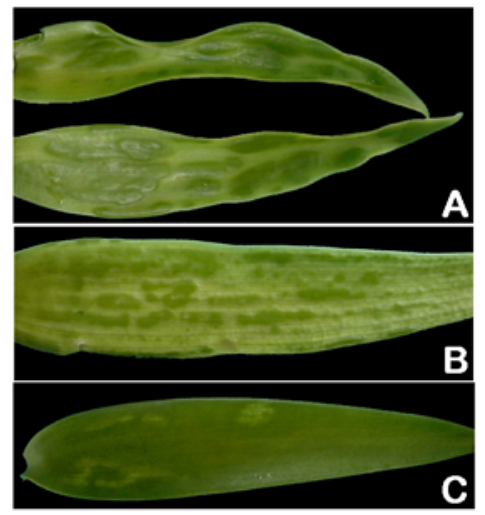

Fig. 2. Symptoms on leaves of Vanilla tahitensis following infection by three potyviruses related to A, Vanilla mosaic virus (isolate WP013), B, Watermelon mosaic virus (isolate WP073), and C, Bean common mosaic virus (isolate WP017).

Table 4. Percent nucleotide identity (above diagonal) and deduced amino acid homology (below diagonal) among partial coat protein sequences for four potyviruses (WP013, WP073, WP086, and WP099) isolated from vanilla in French Polynesia when compared with other viruses ${ }^{\mathrm{a}}$

\begin{tabular}{|c|c|c|c|c|c|c|c|c|c|c|c|}
\hline Virus & WP086 & WP099 & ABMV & DeMV & CABMV & WP073 & WMV & WP013 & DsMV & ZYMV & PVY \\
\hline WP086 & & 98.4 & 94.8 & 90.5 & 81.5 & 81.9 & 82.8 & 75.8 & 73.3 & 76.1 & 72.4 \\
\hline WP099 & 100.0 & $\ldots$ & 95.4 & 91.4 & 81.9 & 81.0 & 81.6 & 76.1 & 73.3 & 77.6 & 72.7 \\
\hline ABMV & 97.2 & 97.2 & $\ldots$ & 92.6 & 81.3 & 81.0 & 82.5 & 77.0 & 74.0 & 76.4 & 71.8 \\
\hline DeMV & 95.4 & 95.4 & 96.3 & $\ldots$ & 80.1 & 77.3 & 79.2 & 75.8 & 73.7 & 75.2 & 70.3 \\
\hline CABMV & 92.6 & 92.6 & 90.8 & 88.9 & $\ldots$ & 77.0 & 77.3 & 70.6 & 72.1 & 77.9 & 71.8 \\
\hline WP073 & 90.8 & 90.8 & 90.8 & 87.1 & 90.8 & $\ldots$ & 96.3 & 74.0 & 71.5 & 75.8 & 73.3 \\
\hline WMV & 90.8 & 90.8 & 92.6 & 88.9 & 90.8 & 98.1 & $\ldots$ & 73.3 & 71.8 & 76.7 & 74.3 \\
\hline WP013 & 87.1 & 87.1 & 85.3 & 83.4 & 85.3 & 86.2 & 86.2 & $\ldots$ & 87.7 & 77.6 & 73.3 \\
\hline DsMV & 85.3 & 85.3 & 86.2 & 83.4 & 83.4 & 85.3 & 87.1 & 98.1 & $\ldots$ & 76.4 & 72.1 \\
\hline ZYMV & 89.9 & 89.9 & 88.0 & 86.2 & 89.9 & 90.8 & 90.8 & 91.7 & 89.9 & $\ldots$ & 74.9 \\
\hline PVY & 84.4 & 84.4 & 83.4 & 80.7 & 84.4 & 86.2 & 86.2 & 84.4 & 83.4 & 85.3 & $\ldots$ \\
\hline
\end{tabular}

a Accession numbers: AB012663, Azuki bean mosaic virus (ABMV); L22907, Watermelon mosaic virus (WMV), and U00122, Dasheen mosaic virus (DsMV). Reference sequences: U23564, Dendrobium mosaic virus (DeMV); AF083558, Cowpea aphid-borne mosaic virus (CABMV); AF127934, Zucchini yellow mosaic virus (ZYMV), and PVI303095, Potato virus Y (PVY). 
from taro to vanilla $(31,32$; K. Farreyrol, unpublished data). These data indicate that WP013 is a strain of VanMV and favor the hypothesis that VanMV is a species distinct from DsMV. The second Potyvirus sp. (WP073; Tables 3 and 4) was identified as a strain of WMV similar to the Tongan vanilla strain (VNV) previously described on $V$. planifolia $(21,30)$. It shares with WMV (accession no. L22907) its serological properties, $96.3 \%$ nucleotide identity, 98\% amino acid homology, over 109 amino acids of the $\mathrm{CP}$ central core, and also its ability to infect melon, watermelon, and $N$. benthamiana (3). To our knowledge, this is the first report of WMV on V. tahitensis. The third Potyvirus sp. was related serologically to the BCMV subgroup. Vine WP099 reacted to antibodies directed against a BCMV strain (Table 3) and the partial CP sequence had 94.8 and $90.5 \%$ nucleotide identities with ABMV and DeMV, respectively, two viruses belonging to the BCMV subgroup $(2,11)$. WP099 also reacted to antibodies against CABMV and WMV (Table 3), but nucleotide identities between WP099 and CABMV and WP099 and WMV did not exceed $83 \%$, which suggests they are distinct potyviruses $(24,27)$. Serological cross-reactivity is a common phenomenon within potyviruses (24) and may explain reactivity of the BCMV-like viruses from vanilla with CABMV and WMV antibodies, as previously reported for BCMV strains $(11,25)$. The viruses belonging to the BCMV subgroup all infect systematically susceptible bean cultivars but several strains are distinguished according to their ability or inability to infect other legume genera $(2,3)$. The two BCMV-like isolates from vanilla induced systemic symptoms on $P$. vulgaris cv. Black Turtle 2 but, unlike DeMV (11), which is the only BCMV strain known to naturally infect an orchid, they were not transmitted to Vigna unguiculata. Although these data suggest that a strain of BCMV naturally infects vanilla in French Polynesia, further biological and molecular analysis is needed to clarify the relationships of this vanilla strain and other members of the BCMV subgroup.

In the 1986 survey (32), VanMV was the only Potyvirus sp. recognized; whereas, in this survey, three different Potyvirus spp. were detected in the Society Islands. An epidemiological appraisal of these potyviruses should be undertaken to determine their interactions between each other and with their natural hosts. To achieve this, there is a need for specific detection tools to distinguish the different viral species. Experimental inoculation of Vanilla tahitensis plants with the three different potyviruses resulted in distinctly different deformation and mosaic patterns (Fig. 2). However, the symptoms are of limited diagnostic value in the field, because they are not expressed all the time and atypical mosaic patterns are found frequently (M.
Grisoni, unpublished data). On the other hand, the high levels of cross reactivity between potyviruses (24) make virus-specific serological tests inappropriate for specific detection of these viruses. The degenerate PCR primers used in this study were primarily designed for amplification of the core $\mathrm{CP}$ region of potyviruses infecting members of Poaceae, although they also are capable of yielding DNA fragments from two dicotyledonous potyviruses (18). In this study, these primers allowed RT-PCR detection of the three distinct Potyvirus spp. infecting vanilla with subsequent identification of the Potyvirus spp. being achieved by cloning and sequencing of the amplified DNA. More rapid and economic methods for specific detection of RT-PCR products have been described $(5,6,19)$, and these may enable the development of accurate detection tools for the potyviruses infecting vanilla.

A significant proportion of the plants surveyed (97/476) were symptomatic but tested negative by ELISA for CymMV and the Potyvirus group. It was discovered subsequently that, for many of these vines (notably those originating from four plots in Raiatea and Huahine), the mosaic and deformation symptoms observed in the field probably are linked to infection by CMV (8).

ORSV appears to be common in vanilla vines in several other Pacific countries (22). However, in French Polynesia, although ORSV often is found in ornamental orchids, only a single ORSV-infected vine was found in the 1986 survey (32) and it was not detected during the current survey. Consequently, it is not considered to be a problem on vanilla in French Polynesia.

\section{ACKNOWLEDGMENTS}

We thank G. Brotherson, W. Brillant, L. S. Fa, B. Faniu, and J. Buillard from the second division of the Rural Development Service for their excellent assistance in the field; V. Vaucherot and N. Laboureau for their invaluable contribution to the laboratory work; and M. Wong, coordinator of the vanilla development project, for his assistance.

\section{LITERATURE CITED}

1. Benezet, H., Picard, E., Côme, B., Grisoni, M., Leclerq Le Quillec, F., Gambin, O., and Jeuffrault, E. 2000. Les virus du vanillier à la Réunion. Phytoma 526:40-42.

2. Berger, P. H., Wyatt, S. D., Shiel, P. J., Silbernagel, M. J., Druffel, K., and Mink, G. I. 1997. Phylogenetic analysis of the Potyviridae with emphasis on legume-infecting potyviruses. Arch. Virol. 142:1979-1999

3. Brunt, A. A., Crabtree, K., Dallwitz, M. J., Gibbs, A. J., Watson L., and Zurcher, E. J. 1996. Plant Viruses Online: Descriptions and Lists from the VIDE Database.

4. Clark, M. F., and Adams, A. N. 1977. Characteristics of microplate method of enzyme linked immunosorbent assay for the detection of plant viruses. J. Gen. Virol. 34:475-483.

5. DiDomenico, N., Link, H., Knobel, R., Caratsch, T., Weschler, W., Loewy, Z. G., and Rosenstraus, M. 1996. Cobas Amplicor: Fully automated RNA and DNA amplification and detection system for routine diagnostic PCR. Clin. Chem. 42:1915-1923.
6. Eun, A. J. C., and Wong, S. M. 1999. Detection of Cymbidium mosaic potexvirus and Odontoglossum ringspot tobamovirus using immuno-capillary zone electrophoresis. Phytopathology 89:522-528.

7. Eun, A. J. C., and Wong, S. M. 2000. Molecular beacons: A new approach to plant virus detection. Phytopathology 90:269-275.

8. Farreyrol, K., Pearson, M. N., Grisoni, M., and Leclercq Le Quillec, F. 2001. Severe stunting of Vanilla tahitensis in French Polynesia caused by Cucumber mosaic virus (CMV), and the detection of the virus in $V$. fragrans in Reunion Island. Plant Pathol. 50:414.

9. Grisoni, M., Côme, B., and Nany, F. 1997. Projet de relance de la vanilliculture dans la région du Sava: Compte rendu de mission à Madagascar du 05 au 18 mai 1997. CIRAD/FOFIFA, Saint Pierre, Réunion, France.

10. Hall, T. A. 1999. BioEdit: A user-friendly biological sequence alignment editor and analysis program for Windows 95/98/NT. Nucleic Acids Symp. Ser. 41:95-98.

11. Hu, J. S., Ferreira, S., Wang, M., Borth, W. B., Mink, G., and Jordan, R. L. 1995. Purification, host range, serology, and partial sequencing of Dendrobium mosaic potyvirus, a new member of the Bean common mosaic virus subgroup. Phytopathology 85:542-546.

12. Hu, J. S., Ferreira, S., Wang, M., and Xu, M. Q. 1993. Detection of Cymbidium mosaic virus, Odontoglossum ringspot virus, Tomato spotted wilt virus and a Potyvirus infecting orchids in Hawaii. Plant Dis. 77:464-468.

13. Hu, W. W., and Wong, S. M. 1998. The use of DIG-labelled cRNA probes for the detection of Cymbidium mosaic potexvirus (CymMV) and Odotonglossum ringspot tobamovirus (ORSV) in orchids. J. Virol. Methods 70:193-199.

14. Jordan, R., Guaragna, M. A., Kinard, G., and Lynn, S. 2002. Detection and first report of Dasheen mosaic virus and a second Potyvirus infecting the terrestrial orchid Spiranthes cernua. Proc. 10th IS Virus Dis. Ornamentals. J. Hammond, ed. Acta Hortic. 568:253-260.

15. Lawson, R H., and Ali, S. 1975 In: Handbook on Orchid Pests and Diseases. American Orchid Society, Cambridge, MA

16. Leclercq Le Quillec, F., Riviere, C., and Lagorce, A. 2001. Spread of Cymbidium mosaic potexvirus and potyviruses in vanilla plants grown in shade houses in Reunion Island. Fruits 56:249-260.

17. Liefting, L., Pearson, M. N., and Pone, S. P. 1992. The isolation and evaluation of two naturally occurring mild strains of Vanilla necrosis potyvirus for control by cross-protection. J. Phytopathol. 136:9-15.

18. Marie-Jeanne, V., Loos, R., Peyre, J., Alliot, B., and Signoret, P. 2000. Differentiation of Poaceae potyviruses by reverse transcriptionpolymerase chain reaction and restriction analysis. J. Phytopathol. 148:141-151.

19. Nolasco, G., Sequeira, Z., Soares, C. Mansinho, A., Bayley, A. M., and Niblett, C. M. 2002. Asymmetric PCR ELISA: Increased sensitivity and reduced costs for the detection of plant viral nucleic acids. Eur. J. Plant Pathol. 108:293-298

20. Pearson, M. N. 1997. Assessment of Vanilla Virus Problem in Ile de la Reunion. The University of Auckland, Auckland, New Zealand.

21. Pearson, M. N., Brunt, A. A., and Pone, S. P. 1990. Some hosts and properties of a Potyvirus infecting Vanilla fragrans (Orchidaceae) in the Kingdom of Tonga. J. Phytopathol. 128:46-54.

22. Pearson, M. N., Jackson, G. V. H., Pone, S. P., and Howitt, R. L. J. 1993. Vanilla viruses in the South Pacific. Plant Pathol. 42:127-131.

23. Seoh, M. L., Wong, S. M., and Zhang, L. 1998. Simultaneous TD/RT-PCR detection of Cymbidium mosaic poyexvirus and Odontoglossum ringspot tobamovirus with a single pair of 
primer. J. Virol. Methods 72:197-204.

24. Shukla, D. D., Colin W. W., and Brunt, A. A. 1994. The Potyviridae. CAB International, Wallingford, UK.

25. Sreenivasulu, P., Demski, J. W., Purcifull, D. E., Christie, R. G., and Lovell, G. R. 1994. A potyvirus causing mosaic disease of sesame (Sesamum indicum). Plant Dis. 78:95-99.

26. Tan, S. W. L., Wong, S. M., and Kini, R. M. 2000. Rapid simultaneous detection of two orchid viruses using LC and/or MALDI-mass spectrometry. J. Virol. Methods 85:93-99.

27. Van Regenmortel, M. H. V., Fauquet, C. M., Bishop, D. H. L., Carstens, E. B., Estes, M. K., Lemon, S. M., Maniloff, J., Mayo, M. A., McGeoch, D. J., Pringle, C. R., and Wickner,
R. B. 2000. Seventh Report of the International Committee on Taxonomy of Viruses. Academic Press, San. Diego, CA.

28. Vejaratpimol, R., Channuntapipat, C., Liewsaree, P., Pewnim, T., Ito, K., Iizuka, M., and Minamiura, N. 1998. Evaluation of enzyme-linked immunosorbent assay for the detection of Cymbidium mosaic virus in orchids. J. Ferment. Bioeng. 86:65-71.

29. Vejaratpimol, R., Channuntapipat, C., Pewnim, T., Ito, K., Iizuka, M., and Minamiura, N. 1999. Detection and serological relationships of Cymbidium mosaic potexvirus isolates. $\mathbf{J}$. Biosci. Bioeng. 87:161-168.

30. Wang, Y. Y., Beck, D. L., Gardner, R. C., and Pearson, M. N. 1993. Nucleotide sequence, se- rology and symptomatology suggest that Vanilla necrosis potyvirus is a strain of Water melon mosaic virus II. Arch. Virol. 129:93 103.

31. Wang, Y. Y., and Pearson, M. N. 1992. Some characteristics of potyvirus isolates from $\mathrm{Va}-$ nilla tahitensis in French Polynesia and the Cook Islands. J. Phytopathol. 135:71-76.

32. Wisler, G. C., Zettler, F. W., and Mu, L. 1987. Virus infections of Vanilla and other orchids in French Polynesia. Plant Dis. 71:1125-1129.

33. Wisler, G. C., Zettler, F. W., and Purcifull, D. E. 1982. A serodiagnostic technique for detection of Cymbidium mosaic and Odotonglossum Ringspot viruses. Phytopathology 72:835-837. 